\title{
Antioxidant and antibacterial activity of extract from two species of mosses: Leucobryum aduncum and Campylopus schmidii
}

\author{
MARIA MASITHO MAKAJANMA ${ }^{1}$, INTAN TAUFIK ${ }^{2}$, AHMAD FAIZAL ${ }^{1, \bullet}$ \\ ${ }^{1}$ Plant Science and Biotechnology Research Group, School of Life Sciences and Technology, Institut Teknologi Bandung. Jl. Ganeca 10, Bandung 40132, \\ West Java, Indonesia. Tel.: +62-22-2511575, vemail: afaizal@sith.itb.ac.id \\ ${ }^{2}$ Microbial Biotechnology Research Group, School of Life Sciences and Technology, Institut Teknologi Bandung. Jl. Ganeca 10, Bandung 40132, West \\ Java, Indonesia
}

Manuscript received: 27 February 2020. Revision accepted: 25 May 2020

\begin{abstract}
Makajanma MM, Taufik I, Faizal A. 2020. Antioxidant and antibacterial activity of extract from two species of mosses: Leucobryum aduncum and Campylopus schmidii. Biodiversitas 21: 2751-2758. Plants produce a plethora of natural compounds of medicinal value. Although most plant-derived drugs have been identified in angiosperms, some species of mosses from the genera Leucobryum and Campylopus also exhibit antioxidant and antibacterial activity. The research aimed to evaluate the antioxidant and antibacterial activities of two species of these genera, Leucobryum aduncum and Campylopus schmidii, that are common in Taman Wisata Alam Gunung Tangkuban Perahu, West Java. Plants were collected, dried, and extracted in $n$-hexane or methanol. Antioxidant activity was evaluated by determining the concentration of extract that resulted in $50 \%$ reduction of 1,1-diphenyl-2-picrylhydrazine (DPPH) in the DPPH assay. These concentrations were $>2000 \mathrm{mg} / \mathrm{L}$ for $L$. aduncum extracts and $1329.02 \pm 7.8 \mathrm{mg} / \mathrm{L}$ for C. schmidii extracts; these large values are consistent with little antioxidant activity. Antibacterial activity was quantified as the ability of the extracts to inhibit the growth of the Gram-negative and Gram-positive bacteria Escherichia coli and Staphylococcus aureus, respectively. Nonpolar extracts of $L$. aduncum inhibited the growth of E. coli $>50 \%$ at a concentration of $32 \mathrm{mg}$ extract/L. Based on combined gas chromatography-mass spectrometry, the antibacterial activity in the non-polar extracts of L. aduncum was attributed to the lipophilic compounds 1-nonadecene, 5-eicosene, and cyclotetracosane. Thus, L. aduncum is a promising candidate as a source of new antibiotics.
\end{abstract}

Keywords: Antibacterial, antioxidant, Campylopus schmidii, Leucobryum aduncum

\section{INTRODUCTION}

Plants produce a vast array of biologically active metabolites that have long been recognized for their extensive and varied medicinal properties. Plant products have also attracted the interest of the pharmaceutical and chemical industries (David et al. 2015; Owen et al. 2017) in their quest for improved drug therapies and to meet the need for novel drug therapies as new diseases emerge and microorganisms develop resistance to existing drugs (Chandra et al. 2017a; Jackson et al. 2018). This quest has led to extensive exploration of these products, much of which has focused on flowering plants, since biologically active compounds accumulate in plant floral organs. However, non-flowering plants, such as mosses and ferns also produce a vast array of biologically active compounds and that the therapeutic potential of these groups merits exploration (Ho et al. 2010; Chandra et al. 2017b; Decker and Reski 2020; Faizal et al. 2020).

Bryophytes, which includes mosses, are cosmopolitan terrestrial plants. They are important in nutrient and water cycles, provide substrates, and regulate microclimates $(\mathrm{He}$ et al. 2016; Spitale 2016; García-Carmona et al. 2020). Bryophytes serve as bioindicators of atmospheric conditions and are used to monitor environments, including agricultural and urban areas (Ah-Peng et al. 2017; Oishi and Hiura 2017). Bryophytes lack well-developed defensive mechanical structures that some other plant groups possess, including lignified cell walls, thorns, spines, and bark. However, they produce a vast array of secondary compounds that serve as defenses against pathogenic microbes and insects (Carella and Schornack 2017; Asakawa and Ludwiczuk 2018; Ludwiczuk and Asakawa 2019). To date, a number of natural products have been isolated and characterized from bryophytes, notably benzenoid compounds, bibenzyl, fatty acid derivatives, flavonoids, phenylpropanoid, sulfur-and nitrogen-containing compounds, and volatile terpenoids (Lu et al. 2019; Ludwiczuk and Asakawa 2019; Peters et al. 2019). Many of these compounds are biologically active as antidiuretic, antiviral, and antifungal agents; have been effective in treating burns and bruises; and have anticancer properties (Sabovljević et al. 2016). More specifically, the mosses Rhodobryum giganteum and $R$. roseum are widely used in China to treat cardiovascular disease; Polytrichum commune has been used as an antipyretic, diuretic, and hemostatic agent; Sphagnum spp. has been employed in surgical pads due to its remarkable absorptive properties (Chandra et al. 2017b). In Indonesia, Domurtiera hirsute, Marchantia paleacea, and Pogonatum cirratum are among the selected mosses which have been indicated for antitumor activities (Nadhifah et al. 2018). Nonetheless, apparently due to their small size, the medicinal attributes 
of mosses are still not as widely recognized as those of flowering plants.

This background inspired us to explore the medicinal potential of bryophytes. Two species of mosses, Leucobryum aduncum, and Campylopus schmidii were selected, which are common in the West Java montane area of Indonesia, specifically in Gunung Tangkuban Perahu. The moss genera Leucobryum and Campylopus have antioxidant, antibacterial, and other medicinal properties (Veljić et al. 2008; Mukhopadhyay et al. 2013; Shin et al. 2016). However, the biologically active compounds of $L$. aduncum and $C$. schmidii are unknown, as well as the nature of their activity. Therefore, this is the first study to assess their antioxidant and antibacterial properties as an initial step in the characterization of these species' potential for utilization as therapeutic agents.

\section{MATERIALS AND METHODS}

\section{Collection of plant materials}

Leucobryum aduncum and Campylopus schmidii were collected from six different locations along the alternative walking track to Kawah Ratu in Taman Wisata Alam Gunung Tangkuban Perahu, Bandung District, West Java, Indonesia $\left(06^{\circ} 45^{\prime} 51.6^{\prime \prime}-06^{\circ} 45^{\prime} 47.9^{\prime \prime} \mathrm{S}\right.$ and 107 $37^{\prime} 16.5^{\prime \prime}-$ $\left.107^{\circ} 37^{\prime} 07.2^{\prime \prime} \mathrm{E}\right)$ at 1700 to $1830 \mathrm{~m}$ asl. (Figure 1). Microclimate data was taken at each sampling point by measuring soil $\mathrm{pH}$, humidity, and temperature; air temperature and humidity; and light intensity.

\section{Sample preparation and extraction}

Each sample was identified as to genus and species, and the identity was verified by Herbarium Bogoriense, LIPI, Cibinong, Bogor District, West Java Province, Indonesia.
After collection, samples were washed under running tap water, dried in a vacuum dryer to a stable dry weight, ground in liquid nitrogen, and extracted following the method of Asakawa et al. (2013).

Samples of 0.3-1 g ground material were extracted with $6 \mathrm{~mL}$ of $96 \% n$-hexane, homogenized with a vortex, and sonicated for $60 \mathrm{~min}$. Extracts were centrifuged at 3,000 rpm for $20 \mathrm{~min}$, the supernatant was transferred to a vial, and the solvent was evaporated. The remaining solids were weighed. This preparation was performed to acquire nonpolar constituents. Furthermore, exhausted extracts were used for sequential extraction using $80 \%$ methanol solvent to acquire the polar constituents. The extracts were stored at $-20^{\circ} \mathrm{C}$ until analysis.

\section{Determination of total phenolic content}

Phenolics have been taken into account for their physiological functions, including antioxidant. Therefore, in this study we measured the total phenolic content based on the Folin-Ciocalteu method with gallic acid as a standard (Ainsworth and Gillespie 2007). This assay produces blue color upon reaction with phenols. The standard curve was obtained by mixing $0.5 \mathrm{~mL}$ of gallic acid solution $(25,50,100,200$, and $400 \mathrm{mg} / \mathrm{L})$ with $1.5 \mathrm{~mL}$ of Folin-Ciocalteu $0.2 \mathrm{~N}$ reagent. The mixture was incubated for $5 \mathrm{~min}$ in $1 \mathrm{~mL} \mathrm{Na} \mathrm{CO}_{3}$ solution and distilled water was added to a final volume of $10 \mathrm{~mL}$. The solution was incubated for $30 \mathrm{~min}$ in the dark, and the absorbance was measured at $765 \mathrm{~nm}$. The polar fraction of the moss extract was dissolved with $80 \%$ methanol to a concentration of $1000 \mathrm{mg} / \mathrm{L}$. The total phenolic content of the extract was calculated as mg gallic acid equivalents (GAE) per $g$ extract using the following formula:

$\mathrm{mg} \mathrm{GAE} / \mathrm{g}$ extract $=[$ extract weight $\times$ diluent factor $] /$ sample weight.
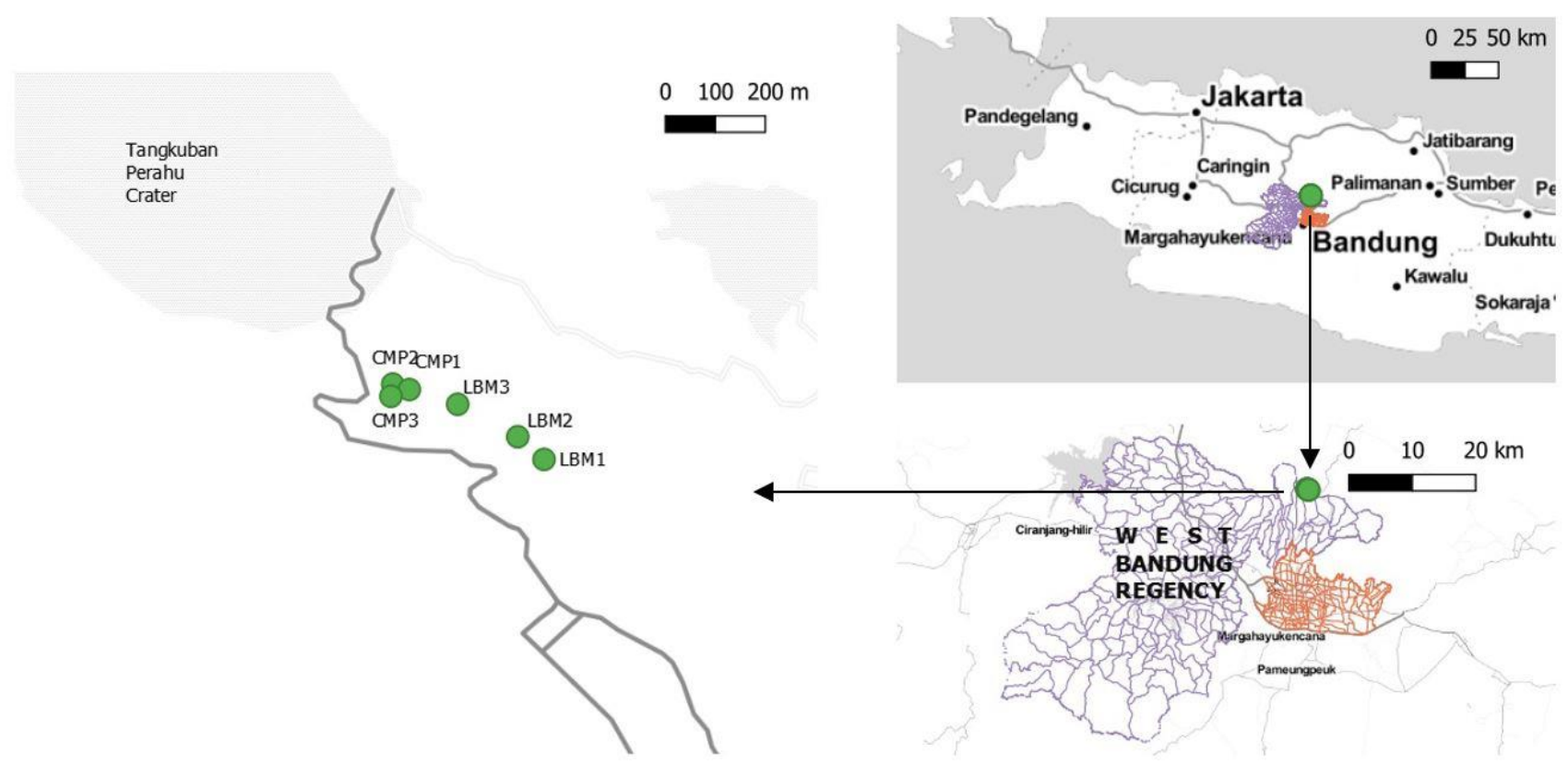

Figure 1. Collection area of Leucobryum aduncum (LBM) and Campylopus schmidii (CMP) along the alternative track to Gunung Tangkuban Perahu Crater, Bandung District, West Java, Indonesia 


\section{Antioxidant activity assay}

Antioxidant activity was determined based on the 1,1diphenyl-2-picrylhydrazine (DPPH) method (Kedare and Singh 2011). DPPH is a stable free radical that is violet in solution but turns colorless when reduced by an antioxidant. Moss extracts $(0.5 \mathrm{~mL})$ of different concentrations $(125,250,500$, and $1,000 \mathrm{mg} / \mathrm{L})$ were mixed with $0.5 \mathrm{~mL}$ of $0.1 \mathrm{mM}$ DPPH solution and incubated for $60 \mathrm{~min}$ in the dark. The absorbance was measured at $517 \mathrm{~nm}$ using $80 \%$ methanol as the blank and $0.5 \mathrm{~mL} 80 \%$ methanol reacted with $0.5 \mathrm{~mL}$ of $0.1 \mathrm{mM}$ $\mathrm{DPPH}$ as the control. The percentage of antioxidant activity was calculated using the following formula:

$\%$ antioxidant activity $=\left[\left(\mathrm{A}_{517}\right.\right.$ control-A517 sample $) / \mathrm{A}_{517}$ control $] \times 100 \%$.

Antioxidant activity is presented as the extract concentration that reduced $50 \%$ of the DPPH (inhibitory concentration $\left.50 ; \mathrm{IC}_{50}\right)$. The activity is classified into four groups: very strong $(<50 \mu \mathrm{g} / \mathrm{mL})$, strong $(50-100 \mu \mathrm{g} / \mathrm{mL})$, moderate $(101-250 \mu \mathrm{g} / \mathrm{mL})$, and weak $(251-500 \mu \mathrm{g} / \mathrm{mL})$, and very weak ( $>500 \mu \mathrm{g} / \mathrm{mL}$ ) (Jun et al. 2003).

\section{Antibacterial activity assay}

The antibacterial activity of the extracts was assessed with a microdilution method (Tan and Lim 2015). Ninety microliters of extract in 2.5\% DMSO (with final concentrations 35.6, 71.1, 142.2, 284.4, 568.9, and 1137.8 $\mathrm{mg} / \mathrm{L}$ were placed into microtiter plate wells. These concentrations were adjusted based on the highest-obtained concentration of moss extracts. Ten microliters of Escherichia coli or Staphylococcus aureus cultures in lysogeny broth (LB) medium $\left(10^{8}\right.$ colony-forming units $[\mathrm{CFU}] / \mathrm{mL}$ ) were added to the wells. The growth control was $2.5 \%$ DMSO, the sterile control was LB medium, and the positive control was kanamycin $(250 \mathrm{mg} / \mathrm{L})$. Optical density (OD) was measured at $595 \mathrm{~nm} 20-24 \mathrm{~h}$ after incubation. The percentage of inhibition was calculated by comparing the difference of OD values with the growth control using the following formula (Veljic et al. 2008):

$\%$ growth inhibition $=100 \%-\left[\left(\mathrm{A}_{595}\right.\right.$ control- $\mathrm{A}_{595}$ sample $) /\left(\mathrm{A}_{595}\right.$ control $\left.) \times 100 \%\right]$.

\section{Gas chromatography-mass spectrometry (GC-MS) analysis}

Extracts were dissolved in $80 \%$ methanol for a final concentration of $1,000 \mathrm{mg} / \mathrm{L}$. The GC-MS analysis was performed using a GC-17A (Shimadzu) and MS QP 5050A with $30 \mathrm{~m} \times 0.25 \mathrm{~mm} \times 0.25 \mu \mathrm{m}$ silica capillary column. A two-microliter injection volume of helium gas was used at a constant flow rate of $1 \mathrm{~mL} / \mathrm{min}$. The temperature started from $40^{\circ} \mathrm{C}$ with an increase of $10^{\circ} \mathrm{C} / \mathrm{min}$ until $280^{\circ} \mathrm{C}$ was reached. Total GC running time was $31 \mathrm{~min}$. The detected compounds were integrated and aligned according to their functional groups. Identification was based on the comparison of retention time and authentic mass spectra data using the existing Wiley MS libraries 2008 (Azar et al. 2019).

\section{Data analysis}

All the experiments involved at least three replicates. Data were reported as means \pm standard deviation (SD) and were analyzed using one-way ANOVA. Mean comparison from each result was contrasted using Duncan's multiple range test. All statistical analyses were performed at $\mathrm{P}<$ 0.05 using an IBM SPSS Statistics 20 Package. The Pearson correlation test was used to determine the correlation between extract concentration and antibacterial activity.

\section{RESULTS AND DISCUSSION}

\section{Plant collection and collection sites}

The average rainfall in the Tangkuban Perahu area ranges from 2.5 to $3.3 \mathrm{~mm} /$ day. Its average temperatures range from approximately 17 to $29^{\circ} \mathrm{C}$ and the average humidity is $69.5 \%$ and ranges from 45 to $97 \%$. The maximum altitude is $2058 \mathrm{~m}$.

The areas from which we sampled $L$. aduncum had a medium canopy cover (50 to $70 \%$ cover). The areas from which we sampled $C$. schmidii had less canopy cover $(<50 \%)$ than the sampling sites of $L$. aduncum. All samples were collected from soil substrate (Figure 2). Although samples were collected at different altitudes (1700-1830 m) and different canopy covers, the microclimate measurements--soil $\mathrm{pH}$, soil humidity, soil temperature, air temperature, and air humidity--were quite similar for the six sampling points (Table 1). Differences in light intensity in the sites were attributed to differences in the canopy cover. Two selected species were observed to enhance the ability to identify them and distinguish them from other species in the same colony. L. aduncum was arranged in dense colonies, had yellowish-green falcate leaves (meaning they tended to curve) that were spirally arranged (Eddy, 1990a) (Figure 3.A). Plants were from 1 to $4 \mathrm{~cm}$ long. C. schmidii plants were also densely arranged, but with dark green leaves that were spirally arranged in an upright orientation (Eddy, 1990b) (Figure 3.B). We also noticed that there were some different species of mosses in the same colony, however, they were not identified as we only focus on L. aduncum and C. schmidii.

\section{Total phenolic content and DPPH scavenging activity}

The total phenolic content and antioxidant activity of the extracts are shown in Table 2 . The $\mathrm{IC}_{50}$ values show the concentration needed to reduce $50 \%$ of the DPPH, a stable free radical. The $\mathrm{IC}_{50}$ value of $L$. aduncum extract could not be determined as none of the extract concentrations reduced DPPH. The $\mathrm{IC}_{50}$ value of $C$. schmidii extract was $1329.02 \pm 7.8 \mathrm{mg}$ extract/L. According to Jun et al. (2003), the antioxidant activity of $L$. aduncum and $C$. schmidii extracts is very weak, which is consistent with the low total phenolic content of both species.

\section{Antibacterial activity}

The correlation between concentration and the percentage of inhibition was analyzed to assess the antibacterial activity (Table 3). No antibacterial activity was apparent in either the polar or non-polar extracts of $C$. schmidii. The antibacterial activity was only detected in the nonpolar extracts of $L$. aduncum. Extracts of $L$. aduncum at 
the lowest concentration evaluated, $32 \mathrm{mg} / \mathrm{L}$, inhibited growth of E. coli by as much as $70 \%$ (Figure 4.A), and growth of $S$. aureus by $40 \%$ (Figure 4.B). While the inhibition of $E$. coli growth was positively correlated with the concentration of extract, the inhibition of growth of $S$. aureus was negatively correlated with the extract concentration: the bacteria grew faster as the extract concentration increased.

Table 1. Microclimate data measured in 6 different locations from which Leucobryum aduncum (LBM) and Campylopus schmidii (CMP) were collected

\begin{tabular}{lllllll}
\hline Microclimate & LBM I & LBM II & LBM III & CMP I & CMP II & CMP III \\
\hline Coordinate & $06^{\circ} 45^{\prime} 51^{\prime \prime}$ S; & $06^{\circ} 45^{\prime} 50.6^{\prime \prime}$ S; & $06^{\circ} 45^{\prime} 48.6^{\prime \prime}$ S; & $06^{\circ} 45^{\prime} 47.9^{\prime \prime}$ S; & $06^{\circ} 45^{\prime} 48^{\prime \prime}$ S; & $06^{\circ} 45^{\prime} 47.9^{\prime \prime}$ S; \\
& $107^{\circ} 37^{\prime} 16.5^{\prime \prime} \mathrm{E}$ & $107^{\circ} 37^{\prime} 13.7^{\prime \prime} \mathrm{E}$ & $107^{\circ} 37^{\prime} 09.3^{\prime \prime} \mathrm{E}$ & $107^{\circ} 37^{\prime} 06.8^{\prime \prime} \mathrm{E}$ & $107^{\circ} 37^{\prime} 07.7^{\prime \prime} \mathrm{E}$ & $107^{\circ} 37^{\prime} 07.2^{\prime \prime} \mathrm{E}$ \\
Canopy coverage (\%) & 60 & 80 & 80 & 40 & 40 & 25 \\
Altitude (m asl.) & 1700 & 1800 & 1824 & 1827 & 1830 & 1830 \\
Soil pH & 5.33 & 6.17 & 6.00 & 5.47 & 5.63 & 6.13 \\
Soil temp. $\left({ }^{\circ} \mathrm{C}\right)$ & 18.63 & 17.97 & 18.77 & 18.77 & 20.10 & 21.54 \\
Soil humidity (\%) & 68 & 47 & 60 & 76 & 72 & 67 \\
Air temp. $\left({ }^{\circ} \mathrm{C}\right)$ & 19.6 & 19.3 & 19.3 & 18.3 & 19.6 & 19.0 \\
Air humidity (\%) & 82 & 87 & 82 & 90 & 79 & 85 \\
Light intensity (Lux) & 2531.00 & 1714.33 & 1834.67 & 2660.67 & 2710.00 & 5903.33 \\
\hline
\end{tabular}
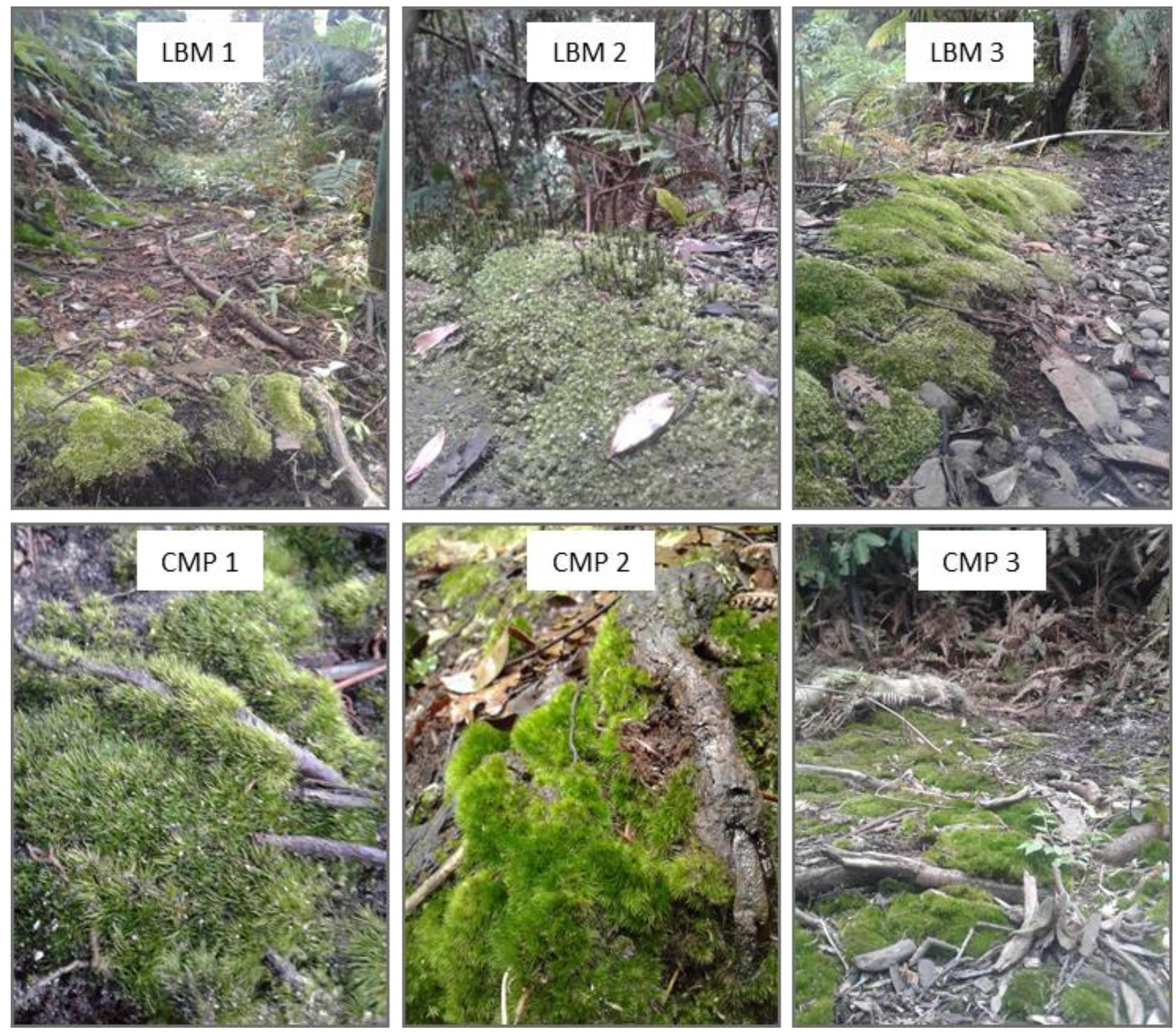

Figure 2. The sample collection habitats of Leucobryum aduncum (LBM) and Campylopus schmidii (CMP) 

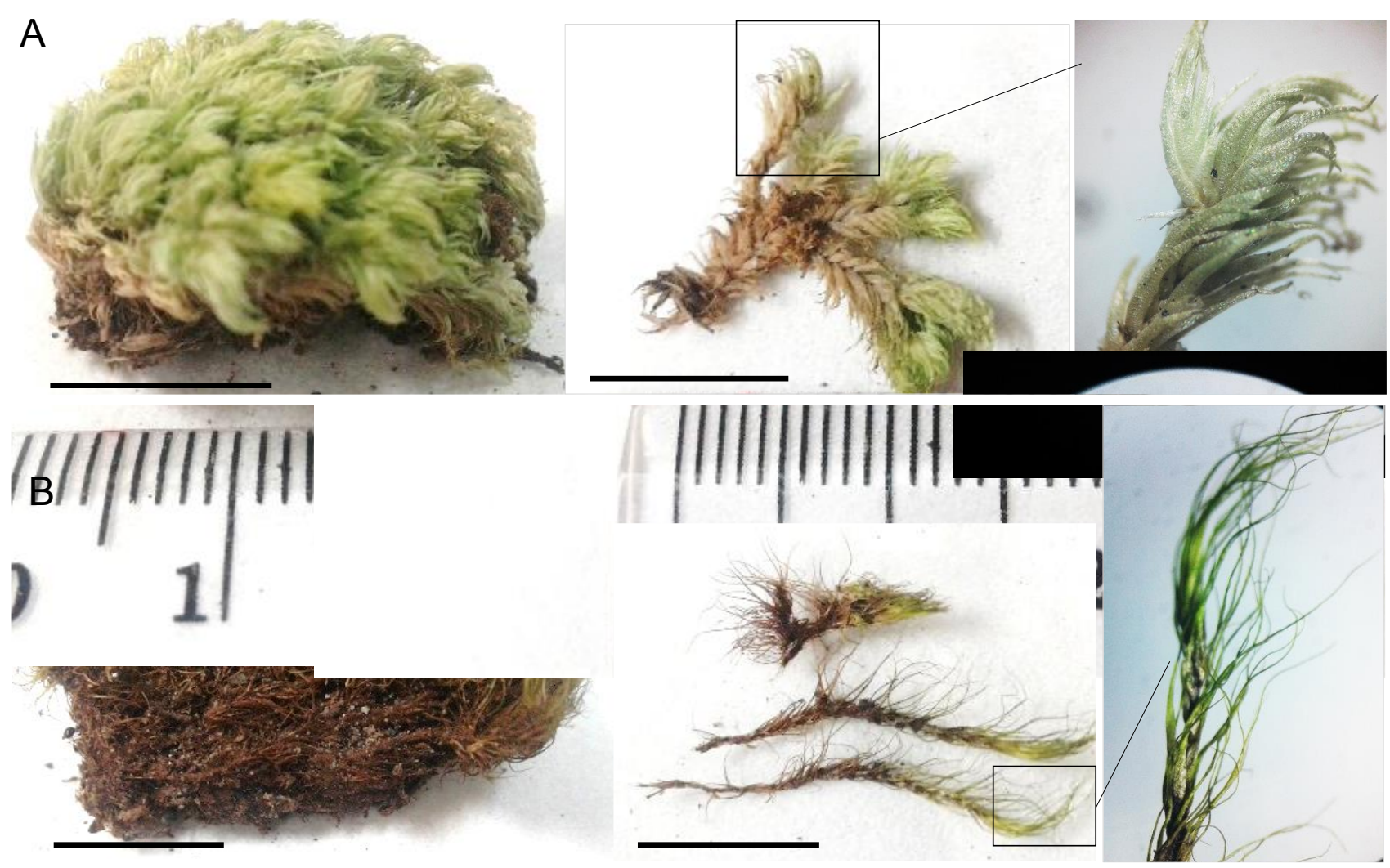

Figure 3. General characteristics of the moss colonies, individual plants, and leaf orientation of Leucobryum aduncum (A) and Campylopus schmidii (B). Bar $=1 \mathrm{~cm}$

\section{GC-MS analysis}

Since antibacterial activity was detected in $n$-hexane extracts of $L$. aduncum, we analyzed the chemical components in these extracts using GC-MS (Table 4). The compounds that were present in the greatest abundance were 3 -octadecene $(14.13 \%)$, 5-eicosene $(10.81 \%)$, and trifluoroacetoxy hexadecane $(9.5 \%)$.

We also analyzed the polar fraction of $L$. aduncum extracts (Table 5). The compounds that were present in the greatest abundance were methyl, 16-methyl-8(Z)heptadecanoate (11.01\%), pentadecanoic acid, 14-methyl-, methyl ester $(10.67 \%)$, and methyl tetradecanoate $(8.36 \%)$.

Table 2. Antioxidant activity (expressed as the concentration required for $50 \%$ reduction of $\mathrm{DPPH}\left[\mathrm{IC}_{50}\right]$ ) and total phenolic content (expressed as gallic acid equivalents [GAE]/g dry weight) of extracts of $L$. aduncum and C. schmidii.

\begin{tabular}{lll}
\hline Species & $\begin{array}{l}\text { Antioxidant } \\
\text { activity }\left[\mathbf{I C}_{\mathbf{5 0}}\right] \\
(\mathbf{m g} \text { extract/L) }\end{array}$ & $\begin{array}{l}\text { Total phenol } \\
\mathbf{( m g} \mathbf{G A E} / \mathbf{g} \\
\text { weight) }\end{array}$ \\
\hline L. aduncum & $>2000$ & $1,2 \pm 0,15^{\mathrm{b}}$ \\
C. schmidii & $1329,02 \pm 7,8$ & $10,7 \pm 1,6^{\mathrm{a}}$ \\
\hline $\begin{array}{l}\text { Different letters indicate significant differences }(P<0.05) \\
\text { between species according to Duncan test. }\end{array}$
\end{tabular}

Table 3. Correlation of inhibition of bacterial growth and extracts from $L$. aduncum and C. schmidii.

\begin{tabular}{lll}
\hline Extract & E. coli & S. aureus \\
\hline L. aduncum & & \\
Methanol & Uncorrelated & - \\
Hexane & $\begin{array}{l}\text { Positive correlation, inhibit } \\
\text { S } \text { schmidii }\end{array}$ & $\begin{array}{l}\text { Negative } \\
\text { correlation }\end{array}$ \\
Methanol & - & \\
Hexane & Uncorrelated & - \\
\hline
\end{tabular}

Table 4. Chemical constituents and their profiles in the $n$-hexane fraction of $L$. aduncum as detected by GC-MS.

\begin{tabular}{lll}
$\begin{array}{l}\text { Retention Relative } \\
\text { time } \\
(\mathbf{m i n})\end{array}$ & $\begin{array}{l}\text { Compound } \\
\text { abundance } \\
\mathbf{( \% )}\end{array}$ & \\
\hline 13.60 & 1,68 & 1-Dodecene \\
16.45 & 4,34 & Octadecane \\
17.43 & 14,13 & 3-Octadecene, (E)- \\
17.64 & 1,11 & 1-Nonadecene \\
18.18 & 0,49 & (3E)-3-Icosene \\
18.63 & 3,67 & Hexadecanoic acid, methyl ester \\
19.43 & 10,81 & 5-Eicosene, (E)- \\
20.81 & 2,04 & Eicosane \\
21.26 & 9,50 & Trifluoroacetoxy hexadecane \\
22.14 & 1,07 & Hexatriacontyl pentafluoropropionate \\
22.94 & 4,70 & Cyclotetracosane \\
24.52 & 1,74 & Heptadecyl heptafluorobutyrate \\
25.70 & 0,20 & 1,3,4-Oxadiazol-2(3H)-one, 5-(4-nitrophenyl)- \\
\hline
\end{tabular}



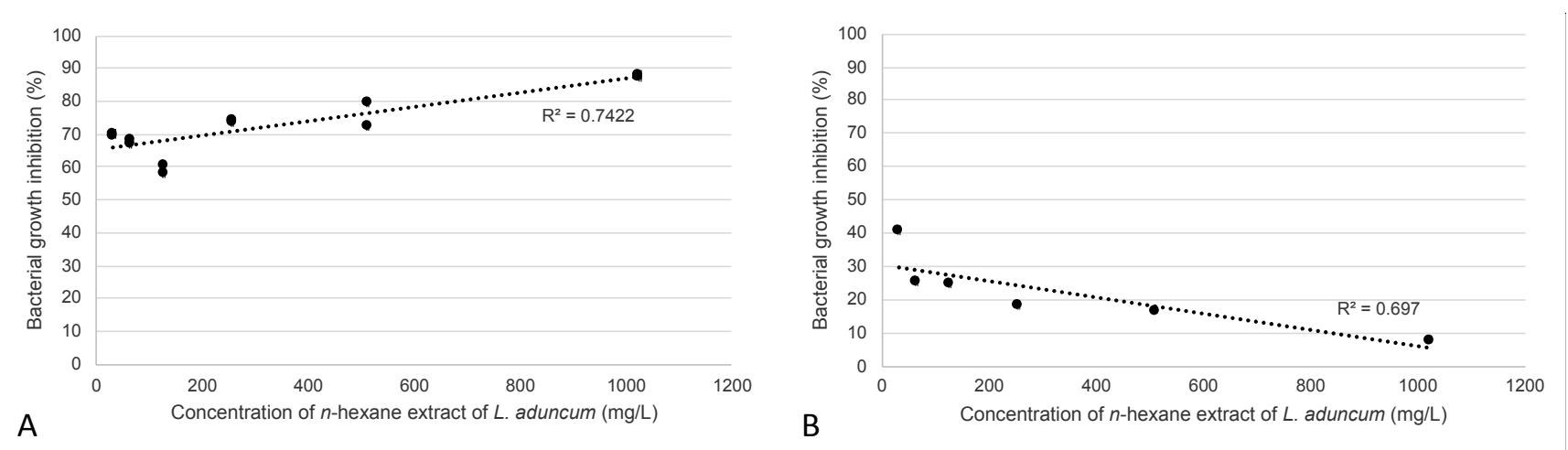

Figure 4. Inhibition of bacterial growth in the presence of $n$-hexane extracts of L. aduncum: A. E. coli, and B. S. aureus

Table 5. Chemical constituents and their profiles in the methanol fraction of L. aduncum as detected by GC-MS.

\begin{tabular}{|c|c|c|}
\hline $\begin{array}{l}\text { Retention } \\
\text { time (min) }\end{array}$ & $\begin{array}{l}\text { Relative } \\
\text { abundance } \\
\text { (\%) }\end{array}$ & Compounds \\
\hline 11,62 & 1,84 & Decanoic acid, methyl ester \\
\hline 14,22 & 6,07 & Dodecanoic acid, methyl ester \\
\hline 16,55 & 8,36 & Methyl tetradecanoate \\
\hline 16,86 & 5,08 & $\begin{array}{l}\text { 3-alpha-acetoxy-18-methoxy- } \\
\text { 16,17-methylenedioxy-delta-(1,6)- } \\
\text { homoerythrinan }\end{array}$ \\
\hline 18,64 & 10,67 & $\begin{array}{l}\text { Pentadecanoic acid, 14-methyl-, } \\
\text { methyl ester }\end{array}$ \\
\hline 20,29 & 11,01 & $\begin{array}{l}\text { Methyl, 16-methyl-8(Z)- } \\
\text { heptadecanoate }\end{array}$ \\
\hline
\end{tabular}

\section{Discussion}

Plant compounds have been an impressive resource for medicinal compounds and will undoubtedly remain so (David et al. 2015). Learning more about this resource is essential if we are to avail ourselves of their potential, and screening for bioactivity is an important tool in this learning. As part of this effort, we have screened two species of bryophytes, the mosses $L$. aduncum and $C$. schmidii, for antioxidant and antibacterial properties. These species are common in high altitude regions of West Java. Previous studies revealed that both Campylopus and were dominantly found in Tangkuban Perahu at 1621-1821 m asl. (Putra et al. 2015), while Leucobryum has been encountered at 1300-1400 m asl. in Cibodas Botanical Garden and in Gunung Gede Pangrango National Park 1600-1700 $\mathrm{m}$ asl. (Azar et al. 2019).

The fact that $C$. schmidii had less canopy cover $(<50 \%)$ could be the reason for higher accumulation of phenolic content than that in L. aduncum. Less canopy cover is associated with higher intensity of solar radiation which could be harmful to moss species due to excessive ultraviolet exposure. In general, plants adapt to this condition by synthesizing more phenolic substances as scavengers of reactive oxygen species and to prevent plant cells from damage (Zuraida et al. 2017; Septiana et al. 2019; Xiong et al. 2019). Therefore, we assessed the free radical scavenging ability of the extracts using a common method, DPPH radical scavenging assay. Both moss species demonstrated very weak antioxidant activity. Since phenolics act as antioxidants, our finding that the phenolic content of the mosses was low as expected and consistent with low antioxidant activity. However, L. juniperoideum has high total phenolic content (119.87 $\pm 11.51 \mathrm{mg} \mathrm{GAE} / \mathrm{g}$ extract) and is considered to have strong antioxidant properties, while $C$. introflexus has moderate antioxidant activity (Mukhopadhyay et al. 2013; Shin et al. 2016).

Certain types of bacteria, such as E. coli, Klebsiella pneumoniae, and Pseudomonas aeruginosa, produce extended-spectrum beta-lactamases, enzymes that can disable many antibiotics. These bacteria are likely to develop antibiotic resistance (Lee et al. 2012), the main concern in the treatment of bacterial infections worldwide, thus, prompting researchers to explore plant-derived natural products for new antibiotic candidates. There have been numerous recent reports of plant products that have antibacterial activity. Notably, five essential oils including tea tree oil, origanum, thyme oil, basil oil, and chamomile blue oil from different herbs possess antibacterial properties against multi-drug resistant Gram-negative bacteria (Sakkas et al. 2016). Several recent studies have also demonstrated that secondary metabolites isolated from mosses such as L. glaucum, Physcomitrella patens, Pogonatum microstomum, and Polytrichum juniperinum have antibacterial activity against Gram-positive bacteria (Veljic et al. 2008; Williams et al. 2016; Karpiński and Adamczak 2017; Yayintas et al. 2017). Taken together, different bacterial isolates may indicate different responses due to their varying strains. Therefore, we assessed the antibacterial activity of $L$. aduncum and C. schmidii extracts on E. coli and $S$. aureus. These bacteria were chosen as they represent Gram-negative bacteria and Gram-positive bacteria, respectively, and have been widely employed for many antibacterial assays using plant extracts (Sakkas et al. 2016; Yasintas et al. 2017).

Several groups have reported that Gram-positive bacteria are more susceptible to plant extracts (Al- 
Ghanayem et al. 2017; Boussaada et al. 2008; Semeniuc et al. 2017). In contrast, we observed that the hexane extract of $L$. aduncum had stronger antimicrobial activity against Gram-negative bacteria than Gram-positive bacteria. GCMS analysis confirmed the presence of 1-nonadecene $(1.11 \%)$, 5-eicosene $(10.81 \%)$, and cyclo-tetracosane (4.7\%), all of which are known antibacterial compounds (Balachandar et al. 2018; Naragani et al. 2016). These lipophilic compounds can impair the binding mechanism of bacterial cell membranes and disrupt the membrane balance, causing cytoplasmic leakage and bacterial cell death (Savoia 2012). In contrast to nonpolar fraction, the methanol fraction of L. aduncum extract showed no antibacterial activity. Despite several compounds were detected on GC-MS analysis from the polar fraction of $L$. aduncum extracts, we assume that these compounds could be interesting for other biological activities, i.e. methyl tetradecanoate acts to stabilize membranes, which is important in treatment of chronic and acute pain and cancer (Ukwubile et al. 2019). These findings suggest that the nonpolar fraction of $L$. aduncum have the promising for new antibiotic.

In conclusion, the $\mathrm{IC}_{50}$ values of extracts of the mosses L. aduncum and C. schmidii were $>2000 \mathrm{mg} / \mathrm{L}$ and $1329.02 \pm 7.8 \mathrm{mg} / \mathrm{L}$, respectively. These values are a measure of antioxidant activity, but such high values are consistent with very weak antioxidant properties. Extracts of $C$. schmidii had no antibacterial activity, while nonpolar extracts of $L$. aduncum exhibited antibacterial activity against $E$. coli with $>50 \%$ inhibition of growth at $32 \mathrm{mg} / \mathrm{L}$, thus, a potential source of antibacterial agents.

\section{ACKNOWLEDGEMENTS}

The authors acknowledge Herbarium Bogoriense, LIPI, Cibinong, Bogor, BKSDA West Java, and PT GRPP Tangkuban Perahu for their help with sample collection and identification. This research was partially funded by the Institut Teknologi Bandung, Indonesia under the scheme of Program Riset ITB 2019 (Contract No. 470/I1.C02.2/KU/2019).

\section{REFERENCES}

Ah-Peng C, Cardoso AW, Flores O, West A, Wilding N, Strasberg D, Hedderson TAJ. 2017. The role of epiphytic bryophytes in interception, storage, and the regulated release of atmospheric moisture in a tropical montane cloud forest. J Hydrol 548: 665-673.

Ainsworth EA, Gillespie KM. 2007. Estimation of total phenolic content and other oxidation substrates in plant tissues using Folin-Ciocalteu reagent. Nat Protoc 2: 875-877.

Al-Ghanayem AA, Sobeai SMA, Alhussaini MS, Joseph B, Saadabi AM 2017. Antibacterial activity of certain Saudi Arabian medicinal plants used in folk medicine against different groups of bacteria. Nusantara Biosci 9: 392-395.

Asakawa Y, Ludwiczuk A, Nagashima F. 2013. Phytochemical and biological studies of bryophytes. Phytochemistry $91: 52-80$

Asakawa Y, Ludwiczuk A. 2018. Chemical constituents of bryophytes: Structures and biological activity. J Nat Prod 81: 641-660.

Azar AWP, Rosleine D, Faizal A. 2019. Secondary metabolite profiles in the methanolic extract of Leucobryum javense isolated from tropical montane forest in West Java, Indonesia. AIP Conf Proc 2120: 030027. DOI: $10.1063 / 1.5115631$

Balachandar R, Karmegam N, Saravanan M, Subbaiya R, Gurumoorthy P. 2018. Synthesis of bioactive compounds from vermicast isolated actinomycetes species and its antimicrobial activity against human pathogenic bacteria. Microb Pathogenesis 121: 155-165.

Boussaada O, Ammar S, Saidana D, Chriaa J, Chraif I, Daami M, Helal AN, Mighri Z. 2008. Chemical composition and antimicrobial activity of volatile components from capitula and aerial parts of Rhaponticum acaule DC growing wild in Tunisia. Microbiol Res 163: 87-95.

Carella P, Schornack S. 2017. Manipulation of bryophyte hosts by pathogenic and symbiotic microbes. Plant Cell Phys 59: 656-665.

Chandra H, Bishnoi P, Yadav A, Patni B, Mishra AP, Nautiyal AR. 2017a. Antimicrobial resistance and the alternative resources with special emphasis on plant-based antimicrobials - a review. Plants 6: 16.

Chandra S, Chandra D, Barh A, Pankaj, Pandey RK, Sharma IP. 2017b. Bryophytes: Hoard of remedies, an ethnomedicinal review. J Trad Compl Med 7: 94-98.

David B, Wolfender J-L, Dias DA. 2015. The pharmaceutical industry and natural products: Historical status and new trends. Phytochem Rev 14:299-315

Decker EL, Reski R. 2020. Mosses in biotechnology. Curr Opin Biotechnol 61: 21-27.

Eddy, A. 1990a. A handbook of Malesian mosses. Leucobryaceae to Buxbaumiaceae. Natural History Musem Publication, London.

Eddy, A. 1990b. A handbook of Malesian mosses. Sphagnales to Dicranales. Natural History Musem Publication, London.

Faizal A, Taufik I, Rachmani AF, Azar, AWP. 2020. Antioxidant and antibacterial properties of tree fern Cyathea contaminans. Biodiversitas 21: 2201-2205.

García-Carmona M, Arcenegui V, García-Orenes F, Mataix-Solera J. 2020. The role of mosses in soil stability, fertility and microbiology six years after a post-fire salvage logging management. J Environ Manag 262: 110287.

He X, He KS, Hyvönen J. 2016. Will bryophytes survive in a warming world?. Perspect Plant Ecol 19: 49-60.

Ho R, Teai T, Bianchini J-P, Lafont R, Raharivelomanana P. 2010. Ferns: From traditional uses to pharmaceutical development, chemical Identification of active principles. In: Kumar A, Fernández H, Revilla MA (eds) Working with Ferns: Issues and Applications. Springer New York.

Jackson N, Czaplewski L, Piddock LJV. 2018. Discovery and development of new antibacterial drugs: Learning from experience? J Antimicrob Chemother 73: 1452-1459.

Jun M, Fu H-Y, Hong J, Wan X, Yang CS, Ho C-T. 2003 Comparison of antioxidant activities of isoflavones from kudzu root (Pueraria lobata Ohwi). J Food Sci 68: 2117-2122.

Karpiński TM, Adamczak A. 2017. Antibacterial activity of ethanolic extracts of some moss species. Herba Pol 63: 11-17.

Kedare SB, Singh RP. 2011. Genesis and development of DPPH method of antioxidant assay. J Food Sci Technol 48: 412-422.

Lee N-Y, Lee C-C, Huang W-H, Tsui K-C, Hsueh P-R, Ko W-C. 2012. Carbapenem therapy for bacteremia due to extended-spectrum- $\beta$ lactamase-producing Escherichia coli or Klebsiella pneumoniae: Implications of ertapenem susceptibility. Antimicrob Agents Chemother 56: 2888-2893.

Lu Y, Eiriksson FF, Thorsteinsdóttir M, Simonsen HT. 2019. Valuable fatty acids in bryophytes-Production, biosynthesis, analysis and applications. Plants 8: 524.

Ludwiczuk A, Asakawa Y. 2019. Bryophytes as a source of bioactive volatile terpenoids-A review. Food Chem Toxic 132: 110649.

Mukhopadhyay ST, Mitra S, Biswas A, Das N, Poddar-Sarkar M. 2013. Screening of antimicrobial and antioxidative potential of selected Eastern Himalayan Mosses. Eur J Med Plants 3: 422-428

Nadhifah A, Khujjah M, Vitara PE, Noviadi I. 2018. Bryophytes in Cibodas Botanical Garden: Diversity and potential uses. Biosantifika 10: $455-463$

Naragani K, Mangamuri U, Muvva V, Poda S, Munaganti RK. 2016 Antimicrobial potential of Streptomyces cheonanensis VUK-A from mangrove origin. Intl J Pharma Pharmaceut Sci 8: 53-57

Oishi Y, Hiura T. 2017. Bryophytes as bioindicators of the atmospheric environment in urban-forest landscapes. Landsc Urban Plan 167: 348355.

Owen C, Patron NJ, Huang A, Osbourn A. 2017. Harnessing plant metabolic diversity. Curr Opin Chem Biol 40: 24-30. 
Peters K, Treutler H, Döll S, Kindt SDA, Hankemeier T, Neumann S. 2019. Chemical diversity and classification of secondary metabolites in nine bryophyte species. Metabolites 9: 222 .

Putra HF, Ambarwati DS, Mubyarsih N, Alesti T. 2015. Physiological characteristics of moss at some altitudes of Tangkuban Perahu Mountain. Jurnal Sumberdaya Hayati 1: 60-63.

Sabovljević MS, Sabovljević AD, Ikram NKK, Peramuna A, Bae H, Simonsen HT. 2016. Bryophytes-an emerging source for herbal remedies and chemical production. Plant Genet Resour 14: 314-327.

Sakkas H, Gousia P, Economou V, Sakkas V, Petsios S, Papadopoulou C. 2016. In vitro antimicrobial activity of five essential oils on multidrug-resistant Gram-negative clinical isolates. J Intercult Ethnopharmacol 5: 212-218.

Savoia D. 2012. Plant-derived antimicrobial compounds: alternatives to antibiotics. Future Microbiol 7: 979-990.

Septiana AT, Handayani I, Winars H. 2019. Antioxidant activity and physicochemical properties of Curcuma zanthorrhiza Roxb added with extract of Ginger (Zingiber officinale Rosc). Jurnal Aplikasi Teknologi Pangan 8: 155-160. [Indonesian]

Shin K-O, Choi K-S, Kim Y-H. 2016. In vitro antioxidative activity of moss extract, and effect of moss on serum lipid level of mice fed with high-fat diet. Trop J Pharma Res 15: 1215-1224.

Spitale D. 2016. The interaction between elevational gradient and substratum reveals how bryophytes respond to the climate. J Veget Sci 27: 844-853
Tan JBL, Lim YY. 2015. Critical analysis of current methods for assessing the in vitro antioxidant and antibacterial activity of plant extracts. Food Chem 172: 814-822.

Ukwubile CA, Ahmed A, Katsayal UA, Ya'u J, Mejida S. 2019. GC-MS analysis of bioactive compounds from Melastomastrum capitatum (Vahl) Fern. leaf methanol extract: An anticancer plant. Sci Afr 3: e00059. DOI: $10.1016 /$ j.sciaf.2019.e00059.

Veljić M, Tarbuk M, Marin PD, Ćirić A, Soković M, Marin M. 2008. Antimicrobial activity of methanol extracts of mosses from Serbia. Pharma Biol 46: 871-875.

Xiong Y, Zhang P, Luo J, Johnson S, Fang Z. 2019. Effect of processing on the phenolic contents, antioxidant activity and volatile compounds of sorghum grain tea. J Cereal Sci 85: 6-14.

Yayintas OT, Alpaslan D, Yuceer YK, Yilmaz S, Sahiner N. 2017. Chemical composition, antimicrobial, antioxidant and anthocyanin activities of mosses (Cinclidotus fontinaloides (Hedw.) P.Beauv. and Palustriella commutata (Hedw.) Ochyra) gathered from Turkey. Nat Prod Res 31: 2169-2173.

Zuraida Z, Sulistiyani S, Dondin S, Irma Herawati S. 2017. Phenolics, flavonoids, and antioxidant activity from Alstonia scholaris R.Br. stem bark extract. Jurnal Penelitian Hasil Hutan 35: 221-230. [Indonesian] 